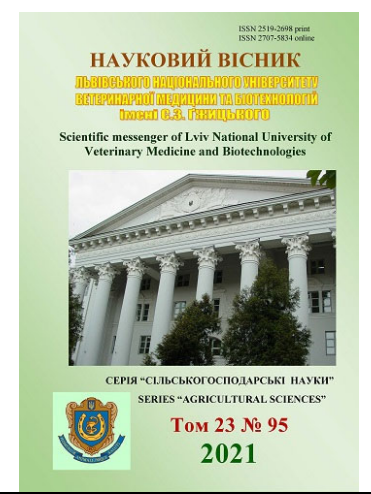

Науковий вісник Львівського національного університету ветеринарної медицини та біотехнодогій імені С.3. Гжицького. Серія: Сільськогосподарські науки

\author{
Scientific Messenger of Lviv National University \\ of Veterinary Medicine and Biotechnologies. \\ Series: Agricultural sciences
}

doi: 10.32718/nvlvet-a9525

https://nvlvet.com.ua/index.php/agriculture

UDC 639.215.2:615.375

\title{
The effect of the drug "Amiksyn" on the immune status of carp
}

\author{
S. I. Kravets, O. V. Krushelnytska
}

Stepan Gzhytskyi National University of Veterinary Medicine and Biotechnologies Lviv, Ukraine

Article info

Received 15.07.2021

Received in revised form 18.08 .2021

Accepted 19.08.2021

Stepan Gzhytskyi National University of Veterinary Medicine and Biotechnologies Lviv, Pekarska Str., 50, Lviv, 79010, Ukraine.

Tel.: +38-098-234-51-12

E-mail: solomiya.tailor@gmail.com
Kravets, S. I., \& Krushelnytska, O. V. (2021). The effect of the drug "Amiksyn" on the immune status of carp. Scientific Messenger of Lviv National University of Veterinary Medicine and Biotechnologies. Series: Agricultural sciences, 23(95), 167-171. doi: 10.32718/nvlvet-a9525

The productivity of pond fish, in particular carp, largely depends on the intensity of use of aquatic bioresources. The aim of the study was to investigate the effect of "Amiksyn" on the immunological parameters of carp fish, namely: the number of $T$ - and B-lymphocytes, immunoglobulins, the level of circulating immune complexes, lysozyme, phagocytic activity and bactericidal activity of serum. 10 fish were selected for hematological and biochemical studies. The research was conducted in the aquarium of the Department of Aquatic Bioresources of Stepan Gzhytskyi NUVMB Lviv. Fish were kept in the pool for 21 days to adapt to the new conditions, and at the beginning of the series of experiments were placed in aquariums with a volume of 200 liters. Aeration and mechanical filtration of water were provided in the tanks. The temperature during the experiments fluctuated slightly and was $18 \pm 1.5^{\circ} \mathrm{C}$. The main hydrochemical parameters corresponded to fish farming standards. In order to adjust the immune response, and thus prevent possible manifestations of fish damage by pathogens, we studied the possibility of using the immunostimulant "Amiksyn", which was used for 5-10-15-20 days and then dosing 5-10-15 mg/kg body weight Pisces. The use of "Amiksyn" at a dose of $10 \mathrm{mg} / \mathrm{kg}$ of fish weight four times during the fifteenday period with an interval of 5 days provided a decrease in the number of T-lymphocytes by $9.1 \%$ and Blymphocytes by $23.0 \%$; caused the activation of non-specific resistance indicators, namely lysozyme activity increased by $28.7 \%$, phagocytic activity of leukocytes increased by $14.0 \%$ and bactericidal activity of serum increased by $19.0 \%$. Therefore, to adjust the immune system and stimulate the metabolic processes of fish in order to prevent the negative effects of various pathogens, the most optimal dose was $10 \mathrm{mg} / \mathrm{kg}$ of fish weight within 15 days of use.

Key words: immune system, immunostimulants, carp, T- and B-lymphocytes, immunoglobulins, phygocytic activity, bactericidal activity of blood serum.

\section{Вплив препарату “Аміксин” на імунний статус коропових риб}

\author{
С. І. Кравець, О. В. Крушельницька
}

Львівський національний університет ветеринарної медицини та біотехнологій імені С. 3. Гжиџького, м. Львів, Україна

Продуктивність ставових риб, зокрема коропових, значною мірою залежить від інтенсивності використання водних біоресурсів. Метою роботи було вивчити вплив препарату “Аміксин” на імунологічні показники коропових риб, а саме: кількість Т- $і$ Влімфоцитів, імуноглобулінів, рівень цииркулююих імунних комплексів, лізоциму, фагоцитарну активність та бактерицидну активність сироватки крові. Для проведення гематологічних та біохімічних досліджень відбирали по 10 рибин. Дослідження проводили в акваріальній кафедри водних біоресурсів ЛНУВМБ імені С. З. Гжиџького. Рибу для адаптації до нових умов протягом 21 доби утримували в басейні, на початку серії експериментів розмішали в акваріуми об'ємом 200 л. В ємкостях була забезпечена аерація та механічна фільтрація води. Температура впродовж дослідів незначно коливалась $і$ складала $18 \pm 1,5{ }^{\circ} \mathrm{C}$. Основні гідрохімічні параметри відповідали рибницько-господарським нормативам. 3 метою коригування імунної відповіді, а отже профілактики можливих проявів ураження риби патогенними агентами, нами проведено дослідження можливості застосування імуностимулятора “Аміксин”, який застосовували протягом 5-10-15 - 20 діб та за подальшого дозування препарату 5 - 10 - 15 мг/кг маси риби. Застосування “Аміксину” в дозі 10 мг/кг маси риби чотириразово впродовж п'ятнадиятиденного терміну з інтервалом 5 
днів забезпечувало зниження кількості Т-лімфоцитів на 9,1\% та В-лімфоцитів на 23,0 \%; зумовлювало активацію неспециифічних показників резистентності, а саме активність лізоциму підвищилась на 28,7\%, фагоцитарна активність лейкоцитів підвищилась на 14,0\% та бактерицидна активність сироватки крові підвищчилась на 19,0\%. Отже, для корегування імунної системи та стимулювання обмінних прочесів організму риби з метою профілактики негативного впливу різного роду патогенних чинників найбільи оптимальною виявилась доза 10 мг/кг маси риби протягом 15 діб застосування.

Ключові слова: імунна система, імуностимулятори, короп, Т- і В-лімфоцити, імуноглобуліни, фагоцитарна активність, бактерицидна активність сироватки крові.

\section{Вступ}

У зв'язку зі зростанням техногенного впливу на середовище існування водних організмів і виникненням загрози для їхнього виживання параметри імунного статусу риби використовуються як показники забруднення води (Kalyn et al., 2020; Butsiak et al., 2021; Hrynevych et al., 2021; Rudenko et al., 2021; Prychepa et al., 2021). Найбільш широко використовуються такі імунологічні параметри, як концентрація лізоциму, антитіл і лейкоцитів у крові, а також тести функціональної активності комплементу, макрофагів і лімфоцитів. Антропогений вплив пригнічує функції імунної системи риби або сприяє розвитку реакцій гіперчутливості та аутоімунних реакцій через дисфункції механізмів регуляції імунної системи, тим самим беручи участь у порушенні гомеостазу організму риби. У результаті спостерігається збільшення кількості хворої риби, зростання інтенсивності і екстенсивності ураженості риби паразитами, зміна сприйнятливості до умовно-патогенної мікрофлори кишечнику (Zabotkina \& Lapirova, 2003; Drohomyretska \& Mazepa, 2008).

Організація імунної системи більшості риб багато в чому передбачає організацію імунної системи вищих хребетних, і риби здатні до прояву всіх форм імунної відповіді, що властиві ссавцям. Проте імунна система риби більш лабільна і сприйнятлива до змін зовнішніх умов. 3 одного боку, це призводить до того, що в несприятливих умовах у риб знижується стійкість до умовно-патогенних і непатогенних симбіонтів і з'являється ризик захворювання інфекційними та інвазійними хворобами, викликаними цими організмами (Onyskovets, 2012; Rudenko et al., 2019). 3 іншого боку, така чутливість імунної системи риби дає можливість розробки нових, більш точних, швидких і недорогих методів визначення стану середовища існування водних тварин, впливу техногенних факторів на живі організми і характеру їхньої відповіді (Saha et al., 2002; Kondrat'eva \& Kitashova, 2002).

Метою роботи було вивчити вплив препарату “Аміксин” на імунологічні показники коропових риб.

\section{Матеріал і методи досліджень}

Для проведення гематологічних та біохімічних досліджень відбирали по 10 рибин. Для досліджень короп усіх груп був відібраний за принципом аналогів (з урахуванням походження, живої маси, віку).

Дослідження проводили у акваріальній кафедри водних біоресурсів ЛНУВМБ імені С. 3. Гжицького. Рибу для адаптації до нових умов протягом 21 доби утримували в басейні, на початку серії експериментів розміщали в акваріуми об'ємом 200 л. В ємкостях була забезпечена аерація та механічна фільтрація води. Температура впродовж дослідів незначно коливалась і складала $18 \pm 1,5{ }^{\circ} \mathrm{C}$. Основні гідрохімічні параметри відповідали рибницько-господарським нормативам.

3 метою коригування імунної відповіді, а отже профілактики можливих проявів ураження риби патогенними агентами нами проведено дослідження можливості застосування імуностимулятора "Аміксин”, який застосовували протягом 5-10 - 15 - 20 діб та за подальшого дозування препарату $5-10-15$ мг/кг маси риби.

Визначення вмісту імуноглобулінів проводили за допомогою простої радіальної імунодифузії за методом Манчіні. Визначення кількості Т- i Bрозеткоутворюючих лімфоцитів крові цьоголіток коропа проводили за методом Д. К. Новікова. Визначення активності лізоциму сироватки крові проводили нефелометричним методом. Визначення фагоцитарної активності лейкоцитів in vitro проводили методом за Е. А. Коста і М. І. Стінки. Визначення циркулюючих імунних комплексів проводили методом, що грунтується на вибірковій преципітації високомолекулярних імунних комплексів, що містяться у сироватці крові, поліетиленгліколем 3 молекулярною масою 6000 Да із подальшим визначенням оптичної щільності шляхом спектрофотометрування при $\lambda=450 \mathrm{HM}$

Аналіз результатів досліджень проводили за допомогою пакета програм Statistica 6.0. Вірогідність різниць оцінювали за t-критерієм Стьюдента. Результати середніх значень вважали статистично вірогідними при * $-\mathrm{P}<0,05$ (ANOVA).

\section{Результати та їх обговорення}

Динаміку концентрації Т- та В- лімфоцитів коропа при застосуванні препарату “Аміксин” наведено у таблиці 1. Загальна концентрація Т-лімфоцитів коропа починала вірогідно зменшуватися на 15-у добу досліду при застосуванні усіх запропонованих доз, а саме: у дозі 5 мг/кг - на 9,4\%; 10 мг/кг - на 9,0\% та 15 мг/кг - на 10,9 \%. При використанні препарату протягом 20 діб - тенденція до зниження зберігалася. Результати були такими: у дозі 5 мг/кг - на 9,1\%; 10 мг/кг - на 9,2 \% та 15 мг/кг - на 11,1\%. Зміни вмісту Т-лімфоцитів крові порівняно із даними контрольної групи були такими: тенденція до зниження концентрації досліджуваного показника спостерігалася протягом усього експерименту, проте ці результати не були вірогідними.

Досліджуючи рівень активних Т-лімфоцитів крові коропа при застосуванні препарату протягом п'яти діб у кількості 5 мг/кг, встановили: результати були невірогідними протягом усього періоду дослідження. 
Таблиця 1

Концентрація Т- і В-лімфоцитів коропа при застосуванні препарату “Аміксин”, \% (M \pm m, n = 10)

\begin{tabular}{cccccc}
\hline \multirow{2}{*}{ Показники } & \multirow{2}{*}{ Доба } & \multirow{2}{*}{ Контроль } & \multicolumn{3}{c}{ препарат “Аміксин” } \\
\cline { 4 - 6 } & 0 & $46,2 \pm 1,2$ & 403 д 5 мг/кг & доза 10 мг/кг & доза 15 мг/кг \\
\hline загальні & 5 & $46,0 \pm 1,6$ & $46,9 \pm 1,3$ & $45,3 \pm 1,3$ & $45,2 \pm 1,3$ \\
Т-лімфоцити, \% & 10 & $45,5 \pm 1,4$ & $45,5 \pm 1,3$ & $43,8 \pm 1,3$ & $43,4 \pm 1,2$ \\
& 15 & $43,7 \pm 1,3$ & $42,2 \pm 1,3$ & $41,2 \pm 1,2$ & $42,2 \pm 1,2$ \\
& 20 & $43,2 \pm 1,2$ & $42,4 \pm 1,2$ & $41,1 \pm 1,2$ & $40,3 \pm 1,2$ \\
В-лімфоцити, \% & 0 & $23,6 \pm 1,4$ & $23,5 \pm 1,2$ & $19,9 \pm 1,1$ & $20,1 \pm 1,2$ \\
& 5 & $23,5 \pm 1,4$ & $24,4 \pm 1,4$ & $20,6 \pm 1,1$ & $21,4 \pm 1,1$ \\
& 10 & $23,5 \pm 1,1$ & $23,1 \pm 1,1$ & $18,1 \pm 1,1^{*}$ & $18,2 \pm 1,1^{*}$ \\
& 15 & $24,9 \pm 1,4$ & $24,5 \pm 1,4$ & $19,7 \pm 1,3 *$ & $20,2 \pm 0,7^{*}$ \\
\hline
\end{tabular}

Порівнюючи отримані результати із даними, отриманими на початку досліджень, тенденція до зниження концентрації активних Т-лімфоцитів спостерігалася, проте вірогідними дані не були. Результати досліджень порівняно із контрольною групою на п'ятнадцяту добу при застосуванні препарату були такими: у дозі 10 мг/кг маси риби концентрація Тлімфоцитів зменшувалася на 7,5\%; у дозі 15 мг/кг маси риби - на 9,1 \%, на двадцяту добу - на 4,9\% відповідно.
Рівень кількості В-лімфоцитів у крові коропа при застосуванні препарату у кількості 5 мг/кг маси риби, наведені дані свідчать про тенденцію до зниження вмісту В-лімфоцитів. При застосуванні препарату у дозі 10 мг/кг маси риби концентрація В-лімфоцитів крові порівняно із контрольною групою зменшувалася на 23,0 \% на 10-у добу та на 20,9 \% - на 15 -у добу експерименту.

\section{Таблиця 2}

Концентрація Т-лімфоцитів коропа при застосуванні препарату “Аміксин”, \% (M \pm m, n = 10)

\begin{tabular}{cccccc}
\hline \multirow{2}{*}{ Показники } & \multirow{2}{*}{ Доба } & \multirow{2}{*}{ Контроль } & \multicolumn{3}{c}{ препарат “Аміксин” } \\
\cline { 3 - 5 } & 0 & $46,6 \pm 1,1$ & $46,7 \pm 1,1$ & $44,4 \pm 1,2$ & $44,5 \pm 1,5$ \\
\hline активні & 5 & $45,3 \pm 1,3$ & $45,3 \pm 1,4$ & $43,4 \pm 1,2$ & $42,4 \pm 1,3$ \\
Т-лімфоцити, \% & 10 & $45,4 \pm 1,6$ & $44,3 \pm 1,4$ & $42,1 \pm 1,3$ & $43,3 \pm 1,3$ \\
& 15 & $46,5 \pm 1,3$ & $44,7 \pm 1,3$ & $41,2 \pm 1,2 *$ & $42,5 \pm 1,2 *$ \\
& 20 & $46,5 \pm 1,3$ & $44,7 \pm 1,3$ & $41,5 \pm 1,2 *$ & $41,5 \pm 1,0^{*}$ \\
\hline & 0 & $33,5 \pm 1,3$ & $32,0 \pm 1,4$ & $32,4 \pm 1,1$ & $32,8 \pm 1,1$ \\
Т- хелпери, \% & 5 & $32,7 \pm 1,5$ & $32,5 \pm 1,5$ & $32,0 \pm 1,3$ & $32,7 \pm 1,3$ \\
& 10 & $32,2 \pm 1,4$ & $31,4 \pm 1,5$ & $33,2 \pm 1,1$ & $32,4 \pm 1,1$ \\
& 15 & $34,4 \pm 1,4$ & $35,0 \pm 1,1$ & $35,3 \pm 1,1$ & $35,6 \pm 1,2$ \\
Т- супресори, \% & 20 & $34,1 \pm 1,4$ & $35,2 \pm 1,1$ & $35,1 \pm 1,1$ & $35,2 \pm 1,2$ \\
\hline & 0 & $12,1 \pm 0,7$ & $12,2 \pm 0,8$ & $11,3 \pm 0,6$ & $11,5 \pm 0,56$ \\
& 10 & $13,4 \pm 0,7$ & $12,2 \pm 0,7$ & $11,3 \pm 0,5$ & $11,2 \pm 0,6$ \\
& 15 & $12,9 \pm 0,7$ & $11,5 \pm 0,7$ & $11,3 \pm 0,4$ & $10,7 \pm 0,9$ \\
& 20 & $11,2 \pm 0,7$ & $11,1 \pm 0,8$ & $10,9 \pm 0,8$ & $10,1 \pm 0,7$ \\
\end{tabular}

При застосуванні “Аміксину” у дозі 15 мг/кг спостерігали зниження концентрації Т-лімфоцитів крові порівняно із контрольною групою на 10-у добу - на 22,3 \% та на $15-$ у добу - на 18,9 \%. Результати досліджень В-лімфоцитів крові показали тенденцію до зниження цього показника, але вони не були вірогідними.

I3 таблиці 2 видно, що при застосуванні препарату “Аміксин” спостерігалася тенденція до зниження вмісту Т-хелперів, хоча вірогідними зміни не були. Аналогічними були і зміни рівня Т-супресорів під впливом “Аміксину”. Зниження їхнього рівня прослідковувалося, проте вірогідними вони не були. За ви- нятком двадцятого дня експерименту, коли при застосуванні препарату “Аміксин” у дозі 10 мг/кг, порівняно із початком досліджень, концентрація Т-супресорів знизилась на $17,9 \%$.

Кількості Ig сироватки крові коропа (табл. 3) змінювалась аналогічно до динаміки $\gamma$-глобулінів. При застосуванні препарату “Аміксин” у кількості 5 мг/кг на 10-у добу експерименту вміст Ig становив $11,1 \pm$ 0,5 г/л; на 15-у добу $-12,1 \pm 0,7$ г/л та на 20-у добу $11,9 \pm 0,7$ г/л за достовірності $\mathrm{P}<0,01$. При застосуванні препарату у дозі $10 \mathrm{мг/кг} \mathrm{маси} \mathrm{риби} \mathrm{вміст} \mathrm{Ig}$ порівняно із контролем збільшувався у 1,$3 ; 1,7$ та 1,5 раза відповідно на 10-у, 15-у та 20-у добу досліду. 
Таблиця 3

Рівень ЦІК та імуноглобулінів сироватки крові коропа при застосуванні імуностимулятора “Аміксин”, \% $(\mathrm{M} \pm \mathrm{m}, \mathrm{n}=10)$

\begin{tabular}{|c|c|c|c|c|c|}
\hline \multirow{2}{*}{ Показники } & \multirow{2}{*}{ Доба } & \multirow{2}{*}{ Контроль } & \multicolumn{3}{|c|}{ препарат “Аміксин” } \\
\hline & & & доза 5 мг/кг & доза 10 мг/кг & доза 15 мг/кг \\
\hline \multirow{5}{*}{$\mathrm{Ig}$} & 0 & $8,0 \pm 0,4$ & $8,0 \pm 0,4$ & $8,8 \pm 0,4$ & $8,4 \pm 0,4$ \\
\hline & 5 & $9,1 \pm 0,4$ & $9,1 \pm 0,4$ & $9,9 \pm 0,4$ & $9,6 \pm 0,4$ \\
\hline & 10 & $9,0 \pm 0,4$ & $11,1 \pm 0,5^{*}$ & $11,9 \pm 0,6^{*}$ & $10,4 \pm 0,5^{*}$ \\
\hline & 15 & $8,4 \pm 0,4$ & $12,1 \pm 0,7^{*}$ & $14,1 \pm 0,7^{*}$ & $13,4 \pm 0,7^{*}$ \\
\hline & 20 & $8,3 \pm 0,4$ & $11,9 \pm 0,7^{*}$ & $12,8 \pm 0,7^{*}$ & $13,8 \pm 0,78^{*}$ \\
\hline \multirow{5}{*}{ ЦІК, ммоль/л } & 0 & $50,1 \pm 1,2$ & $50,9 \pm 1,3$ & $49,4 \pm 1,3$ & $49,8 \pm 1,3$ \\
\hline & 5 & $50,4 \pm 1,3$ & $50,3 \pm 1,2$ & $51,0 \pm 1,2$ & $51,2 \pm 1,2$ \\
\hline & 10 & $50,7 \pm 1,2$ & $50,8 \pm 1,1$ & $51,1 \pm 1,3$ & $50,7 \pm 1,3$ \\
\hline & 15 & $51,0 \pm 1,2$ & $51,2 \pm 1,3$ & $50,3 \pm 1,3$ & $49,9 \pm 1,3$ \\
\hline & 20 & $50,8 \pm 1,2$ & $51,0 \pm 1,3$ & $49,4 \pm 1,0$ & $50,0 \pm 1,3$ \\
\hline
\end{tabular}

Концентрація Ig крові коропа при застосуванні препарату у дозі 15 мг/кг сприяла зростанню концентрації імунних білків порівняно із контрольною групою на 10-у добу - на 1,4 \%; на 15 -у добу - на 5,0 \% та на 20-у добу - на 5,5\%. Вірогідних змін вмісту циркулюючих імунних комплексів встановлено не було.

При дослідженні впливу імуностимулятора “Аміксин” на фактори природної неспецифічної резистентності коропа встановили, що їх співвідношення змінювалося залежно від дози препарату та тривалості його застосування. Вміст досліджуваних факторів природної неспецифічної резистентності, достовірно зростав на 15-20-у добу застосування препарату (табл. 4)

У процесі дослідження лізоциму крові коропа встановили, що його рівень вірогідно збільшувався на 15-20-у добу досліду при застосуванні препарату у дозі 10 мг/кг - на 18,4 \%; а у дозі 15 мг/кг - на 16,8 \%. Використання препарату протягом 20 діб показало, що тенденція до зростання зберігалася і становила 16,8 \% та 14,2 \% відповідно. Проте за дози препарату 5 мг/кг маси риби вірогідності не встановили, хоча прослідковувалось збільшення концентрації досліджуваного показника.

Під час дослідження фагоцитарної активності лейкоцитів встановлено, що при застосуванні препарату у кількості 10 мг/кг маси риби результати були такими: на 15 -у добу - 13,7 \%, на 20-у добу - 12,1\%; у дозі 15 мг/кг маси риби - 7,89 \%; 7,11 \% відповідно до даних, отриманих на початку досліджень.

Вірогідним $(\mathrm{P}<0,05)$ було зростання концентрації фагоцитарної активності лейкоцитів при застосуванні препарату “Аміксин” у дозі 15 мг/кг маси риби, а саме: на 15 -у добу він зростав на $4,6 \%$, а на 20 -у добу - на 3,6 \%.

\section{Таблиця 4}

Фактори природної неспецифічної резистентності коропа при застосуванні імуностимулятора “Аміксин” $(\mathrm{M} \pm \mathrm{m}, \mathrm{n}=10)$

\begin{tabular}{cccccc}
\hline \multirow{2}{*}{ Показник } & \multirow{2}{*}{ Доба } & \multirow{2}{*}{ Контроль } & \multicolumn{3}{c}{ препарат “Аміксин” } \\
\cline { 3 - 5 } & 0 & $11,3 \pm 0,5$ & $11,5 \pm 0,6$ & $11,3 \pm 0,6$ & $11,4 \pm 0,5$ \\
Лізоцим, \% & 5 & $11,7 \pm 0,7$ & $11,9 \pm 0,6$ & $12,5 \pm 0,7$ & $12,7 \pm 0,7$ \\
& 10 & $11,5 \pm 0,5$ & $12,7 \pm 0,7$ & $13,0 \pm 0,7$ & $13,3 \pm 0,7$ \\
& 15 & $11,5 \pm 0,6$ & $12,9 \pm 0,7$ & $14,8 \pm 0,7^{*}$ & $14,7 \pm 0,7^{*}$ \\
& 20 & $11,4 \pm 0,8$ & $12,7 \pm 0,8$ & $14,6 \pm 0,7^{*}$ & $14,5 \pm 0,8^{*}$ \\
\hline \multirow{2}{*}{ ФА, \% } & 0 & $37,2 \pm 1,2$ & $36,2 \pm 1,2$ & $37,2 \pm 1,3$ & $38,0 \pm 1,9$ \\
& 5 & $38,0 \pm 1,7$ & $39,0 \pm 1,8$ & $39,0 \pm 1,7$ & $38,9 \pm 1,6$ \\
& 10 & $38,1 \pm 1,8$ & $39,1 \pm 1,6$ & $40,5 \pm 1,4$ & $41,1 \pm 1,3$ \\
& 15 & $37,1 \pm 1,3$ & $38,1 \pm 1,6$ & $42,3 \pm 1,7^{*}$ & $41,0 \pm 1,5^{*}$ \\
БАСК, \% & 20 & $37,1 \pm 1,4$ & $39,0 \pm 1,7$ & $41,7 \pm 1,4^{*}$ & $40,7 \pm 1,4^{*}$ \\
\hline & 0 & $25,1 \pm 1,3$ & $25,6 \pm 1,4$ & $24,9 \pm 1,6$ & $25,0 \pm 1,2$ \\
& 10 & $25,9 \pm 1,4$ & $26,3 \pm 1,5$ & $25,0 \pm 1,2$ & $27,3 \pm 1,2$ \\
& 15 & $25,4 \pm 1,5$ & $26,6 \pm 1,5$ & $27,2 \pm 1,2$ & $27,4 \pm 1,2$ \\
& 20 & $25,3 \pm 1,0$ & $26,9 \pm 1,5$ & $29,4 \pm 1,4^{*}$ & $30,1 \pm 1,4^{*}$ \\
\hline
\end{tabular}

При застосуванні препарату протягом усього експерименту виявлено тенденцію до зростання рівня бактерицидної активності сироватки крові, за винятком даних, отриманих на 15-у добу у дозах 10 та 15 мг/кг маси риби “Аміксину” порівняно із початком досліду, що становили $29,4 \pm 1,4 \%(\mathrm{P}<0,05)$ та $30,1 \pm$ $1,4 \%(\mathrm{P}<0,01)$.

Порівняно із контрольною групою результати були такими: загальна тенденція до зростання показника зберігалася, але вірогідним було збільшення рівня досліджуваного показника лише на п’ятнадцяту добу 
при застосуванні препарату у дозі 10 і 15 мг/кг маси риби, він зростав на 16,2 \% і 19,0\% відповідно.

\section{Висновки}

Застосування “Аміксину” у дозі 10 мг/кг маси риби чотириразово впродовж п’ятнадцятиденного терміну 3 інтервалом 5 днів забезпечувало зниження кількості Т- лімфоцитів на 9,1\% та В- лімфоцитів на $23,0 \%$; зумовлювало активацію неспецифічних показників резистентності, а саме активність лізоциму підвищилась на 28,7 \%, фагоцитарна активність лейкоцитів підвищилась на 14,0 \% та бактерицидна активність сироватки крові підвищилась на 19,0 \%.

Для корегування імунної системи та стимулювання обмінних процесів організму риби з метою профілактики негативного впливу різного роду патогенних чинників найбільш оптимальною є доза 10 мг/кг маси риби протягом 15 діб застосування.

\section{References}

Butsiak, H. A., Butsiak, V. I., Gutyj, B. V., Kalyn, B. M., Muzyka, L. I., Stadnytska, O. I., Luchyn, I. S., Rozputnii, O. I., Kachan, L. M., Melnichenko, Yu. O., Sliusarenko, S. V., Bilkevich, V. V., \& Leskiv, K. Y. (2021). Migration of mobile forms of heavy metals into the vegetative mass of plants under local humancaused load. Ukrainian Journal of Ecology, 11(1), 239-343. doi: 10.15421/2021_50.

Drohomyretska, I. Z., \& Māepa, M. A. (2008). Osoblyvosti fahotsytarnoi aktyvnosti leikotsytiv krovi Syprinus carpio L. pid vplyvom ioniv kadmiiu ta nikeliu. Pryrodnychyi almanakh. Biol. Nauky, 10, 5360 (in Ukrainian).

Hrynevych, N., Prychepa, M., Kovalenko, Yu., Vodianitskyi, O., Svitelskyi, M., Fotin, O., Zahorui, L., Zharchynska, V., Gutyj, B., Kulish, S., Honcharenko, V., Velesyk, T., Sachuk, R., Stravsky, Ya., \& Boltyk, N. (2021). The role of macrophytes in waterfowl reproduction. Ukrainian Journal of Ecology, 11(2), 320326. doi: 10.15421/2021_117.

Kalyn, B. M., Khromova, M. V., Vishchur, V. Ia., Butsiak, H. A., Kropyvka, S. I., \& Gutyj, B. V. (2020). Estimation of quality of surface water of Dniester river basin within Lviv and Khmelnytsk regions. Ukrainian Journal of Ecology, 10(6), 127-132. doi: 10.15421/2020_271.
Kondrat'eva, I. A., \& Kitashova, A. A. (2002). Sovremennye predstavlenija ob immunnoj sisteme ryb. Funkcionirovanie i reguljacija immunnoj sistemy ryb. Immunologija, 2, 97-101 (in Russian).

Onyskovets, M. (2012). Pokaznyky imunnoho statusu ryb u biomonitorynhu vazhkykh metaliv u navkolyshnomu seredovyshchi. Visnyk of the Lviv University. Series BIology, 60, 190-197. URL: http://prima.lnu.edu.ua/ faculty/biologh/wis/60/5/20/20.pdf (in Ukrainian).

Prychepa, M., Hrynevych, N., Kovalenko, Yu., Vodianitskyi, O., Svitelskyi, M., Khomiak, O., Prysiazhniuk, N., Ishchuk, O., Sliusarenko, A., Kunovskii, J., Mihalskiy, O., Heiko, L., Trofymchuk, A., Gutyj, B., \& Levkivska, N. (2021). Diversity of aquatic animals in water bodies Opechen' (Dnipro floodplain, Ukraine). Ukrainian Journal of Ecology, 11 (3), 285-291. doi: 10.15421/2021_173.

Prychepa, M., Hrynevych, N., Martseniuk, V., Potrokhov, O., Vodianitskyi, O., Khomiak, O., Rud, O., Kytsokon, L., Sliusarenko, A., Dunaievska, O., Gutyj, B., Pukalo, P., Honcharenko, V., Yevtukh, L., Bozhyk, L., Prus, V., \& Makhorin, H. (2021). Rudd (Scardinius Erythrophthalmus 1., 1758) as a bioindicator of anthropogenic pollution in freshwater bodies. Ukrainian Journal of Ecology, 11 (2), 253-260. doi: 10.15421/2021_108.

Rudenko, O. P., Lytvyn, N. A., \& Gutyj, B. V. (2021). Assessment of microbiological indicators and monitoring of a sociological survey of the quality of sources in the city of Lviv. Scientific Messenger of Lviv National University of Veterinary Medicine and Biotechnologies. Series: Agricultural sciences, 23(94), 81-85. doi: 10.32718/nvlvet-a9415.

Rudenko, O. P., Paranjak, R. P., Kovalchuk, N. A., Kit, L. P., Hradovych, N. I., Gutyj, B. V., Kalyn, B. M., Sukhorska, O. P., Butsiak, A. A., Kropyvka, S. I., Petruniv, V. V., \& Kovalska, L. M. (2019). Influence of seasonal factors on carp fish immune reactivity. Ukrainian Journal of Ecology, 2019, 9(3), 168-173. URL: https://www.ujecology.com/articles/influence-ofseasonal-factors-on-carp-fish-immune-reactivity.pdf.

Saha, N. R., Usami, T., \& Suzuki, Y. (2002). Seasonal changes in the immune activities of common carp (Cyprinus carpio). Fish Physiology and Biochemistry, 26(4), 379-387. doi: 10.1023/B:FISH.0000009275.25834.67.

Zabotkina, E. A., \& Lapirova, T. B. (2003). Vlijanie tjazhelyh metallov na immunofiziologicheskij status ryb. Uspehi sovremennoj biologii, 123(4), 401-408 (in Russian). 